\title{
Behaviour of Single and Group Helical Piles in Sands from Model Experiments
}

\author{
Jongho Bak, Byung-hyun Choi, Junwon Lee, Jonghwan Bae, Kicheol Lee and Dongwook Kim \\ Dept of Civil and Environmental Engineering, Incheon National University, Republic of Korea
}

\begin{abstract}
Mainly used foundations of oil sand plants are drilled shafts or driven piles. As environmental regulations become increasingly strict, complete removal of the foundation is becoming more important during the step of plant dismantling. However, it is difficult to remove completely drilled shafts or driven piles which are deeply installed to obtain more bearing capacity. Helical piles can be easily removed and recycled after use. This study analyses the behaviour of single and group helical piles in sands. For single helical piles, pile load tests of helical piles were conducted varying helix spacing, rotation speed and weight of axial loading during pile installation. The single pile tests determined the optimal helix spacing, rotation speed, weight of axial loading during pile installation. And then, pile load test of group helical piles was performed varying pile spacing from the centre place of upper connector based on the optimal installation conditions.
\end{abstract}

\section{Introduction}

Northern Alberta in Canada has approximately 170 billion barrels of oil reserves. This is the third largest oil reserves in the world after Venezuela and Saudi Arabia. However, the oil in this place is mixed with sands. Therefore, it is necessary to install oil sand plant that extracts crude oil from oil sands.

The foundation of the plant structure is typically used as drilled shafts or driven piles. Drilled shafts cause additional cost of quality management for concrete curing in cold region. Driven piles induce the noise and vibration during pile installation. Especially, with more strict environmental regulations, it is becoming important to whether complete removal of the foundation during the step of plant dismantling. However, Drilled shafts or Driven piles are installed in deeper depths and stronger places to gain more bearing capacity, and it is difficult to completely remove.

Helical pile that is subject of this study consists of a steel central shaft and helices attached to the central shaft. The helical pile is just installed by applying torque at the pile head with a small equipment [1]. So, helical foundation has excellent performances for construction, and it is easy to install even in low-accessibility areas [2]. Also, helical pile has environmental advantage of being easy to pull out and also economic advantage of recycling for drawn pile. However, most of helical piles have a regular shape, and the research of pile bearing capacity is insufficient according to the shape of helix [3].

This study analyses the behaviour of single and group helical piles in sands from experiment results. Pile load test for a single helical pile was conducted varying helix spacing, rotation speed and weight of axial loading during pile installation. From the single pile load tests, optimal installation conditions for helix spacing, rotation speed and weight of loading were determined based on the ultimate loads of helical piles.

Furthermore, behaviour of group helical piles was analysed to maximize the pile bearing capacity depending on pile distance from the centre place of upper connector based on the optimal conditions of single pile tests.

\section{Background}

\subsection{Ultimate load of Davisson`s criterion}

Equation (1) for ultimate load was proposed by Davisson [4-5] (Fig. 1).

$$
\mathrm{W}_{\mathrm{ult}}=0.004 \mathrm{~L}_{\mathrm{r}}+\frac{\mathrm{B}}{120}+\frac{\mathrm{Q}_{\mathrm{ult}} \mathrm{L}}{\mathrm{A}_{\mathrm{p}} \mathrm{E}_{\mathrm{p}}}
$$

where, $Q_{\text {ult }}$ : ultimate load, $\mathrm{w}_{\text {ult }}$ : pile displacement at $\mathrm{Q}_{\text {ult }}$ (unit is the same as $\mathrm{L}_{\mathrm{r}}$ ), $\mathrm{L}_{\mathrm{r}}$ : reference length of $1 \mathrm{~m}$, $B$ : pile diameter (unit is the same as $L_{r}$ ), $L$ : pile length (unit is the same as $\mathrm{L}_{\mathrm{r}}$ ), $\mathrm{A}_{\mathrm{P}}$ : cross-sectional area of the pile (unit of $\mathrm{L}_{\mathrm{r}}^{2}$ ), and $\mathrm{E}_{\mathrm{p}}$ : elastic modulus of the pile.

\subsection{Bearing capacity methods of helical pile}

The smaller bearing capacity calculated by individual bearing method and cylindrical shear method is determined as the bearing capacity of helical pile [6].

Individual bearing method assumes that helices attached to the pile shaft have end bearing capacities, respectively (Fig. 2(a)). And cylindrical shear method 
assumes that the soils located between the helices cause frictional resistance like shaft resistance (Fig. 2(b)).

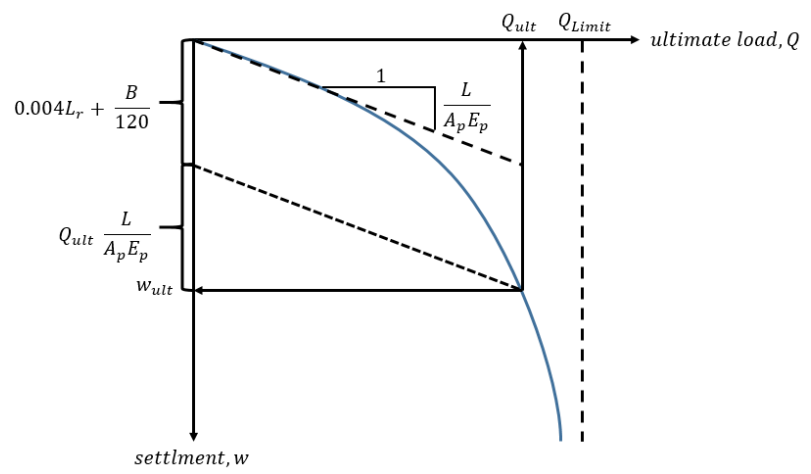

Fig. 1. Davisson`s criterion method [4-5]

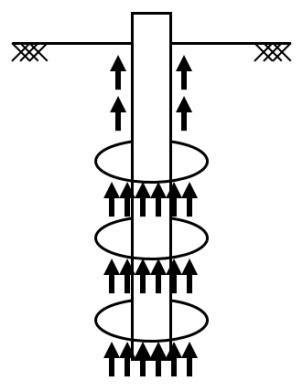

(a)

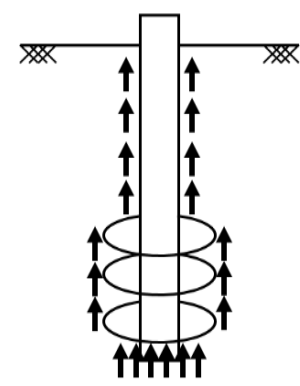

(b)
Fig. 2. Schematic representation of (a) Individual method and (b) Cylindrical shear method

\section{Testing method}

\subsection{Two types of helical piles}

Two types of helical piles were produced as one-sixth model of conventional pile that has $50 \mathrm{~mm}$ shaft diameter, $750 \mathrm{~mm}$ total length, and $100 \mathrm{~mm}$ helix diameter.

The produced helical piles were created to simulate two kinds of bearing capacity methods; Individual bearing method and cylindrical shear method. The helical pile with $50 \mathrm{~mm}$ helix spacing is assumed as cylindrical shear method, and that with $150 \mathrm{~mm}$ helix spacing is assumed as individual bearing method (Fig. 3).

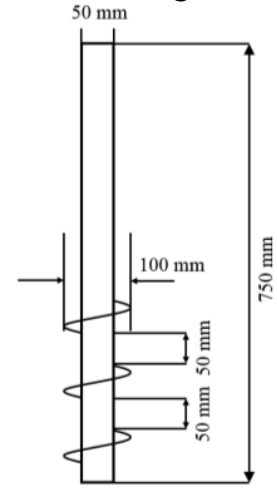

(a)

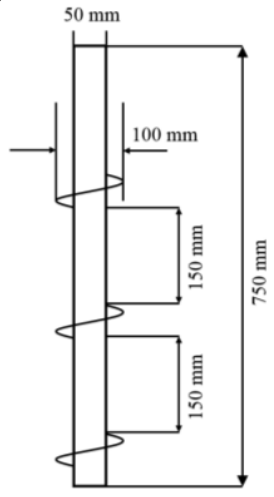

(b)
Fig. 3. Schematic description; Helix spacing of (a) $50 \mathrm{~mm}$ and (b) $150 \mathrm{~mm}$

\subsection{Testing ground}

In order to create an environment similar to the oil sand plant, sands were used for the testing ground. Material properties of used sands are shown in Table 1. The soils are poorly-graded sands with non-plastic.

The cylindrical soil tank and rectangular large soil tank were manufactured for helical pile load test. For single helical pile, diameter and height of cylindrical soil tank are $1000 \mathrm{~mm}, 1200 \mathrm{~mm}$, respectively (Fig. 4(a)). For group helical pile, length, width and height of rectangular large soil tank are $3000 \mathrm{~mm}, 2000 \mathrm{~mm}$ and $1200 \mathrm{~mm}$, respectively (Fig. 4(b)).

The compaction of the cylindrical soil tank was carried out using sand pluviator, and that of the rectangular large soil tank was carried out using hand vibrator (Fig. 5). The uniformity of sands was checked using cone penetration.

Table 1. Material properties of sands used in this study.

\begin{tabular}{|c|c|}
\hline Material properties & Values \\
\hline Classification of soil & SP (poorly-graded sands) \\
\hline Plastic index, PI & 0 (Non plastic) \\
\hline $\begin{array}{c}\text { Internal friction angle, } \Phi \\
\text { Maximum dry unit weight, } \\
\gamma_{\mathrm{d}}\end{array}$ & $33.82^{\circ}$ \\
\hline
\end{tabular}

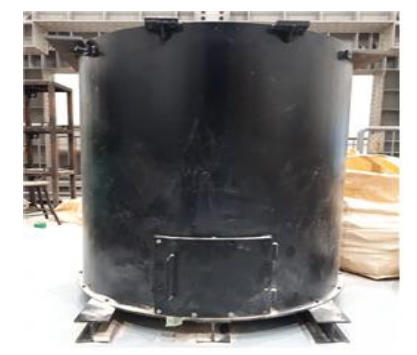

(a)

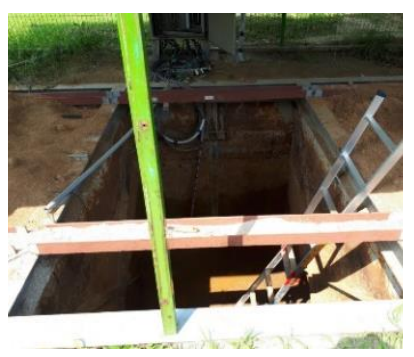

(b)
Fig. 4. Picture of (a) Cylindrical soil tank and (b) Rectangular large soil tank

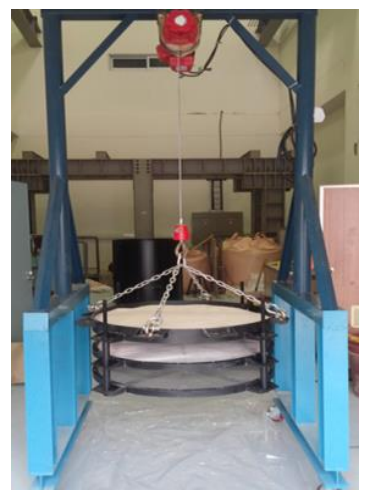

(a)

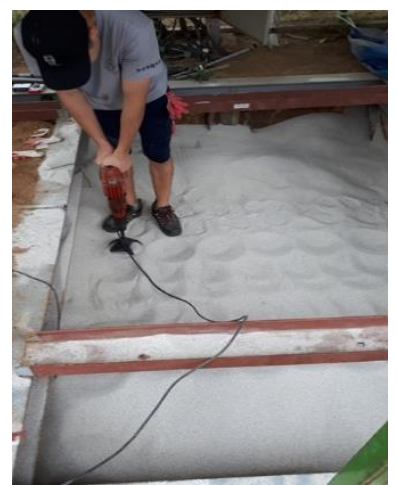

(b)
Fig. 5. Compaction methods of testing ground; (a) Sand pluviator and (b) Hand vibrator 


\subsection{Pile load test}

The devices of helical pile installation is shown in Fig. 6 . The helical piles are connected to the rotational installation device, and are penetrated in sands varying rotation speed $(15 \mathrm{rpm}$ or $30 \mathrm{rpm})$ and weight (45 kg or $85 \mathrm{~kg}$ ) of axial loading during pile installation. After pile installation, the jacking system and the load cells are installed on the pile head (Fig. 7(a)). And finally, pile load test are conducted by measuring the axial load and the settlement. The ultimate load are determined from the load-settlement curve based on Davisson's criterion.

The group helical piles consist of three individual helical piles and an upper steel connector (Fig. 7(b)). Individual pile distance from the center point of upper connector is assumed as $150 \mathrm{~mm}$ ( 3 times of shaft diameter, 3D), $250 \mathrm{~mm}$ (5D), $300 \mathrm{~mm}$ (6D), $450 \mathrm{~mm}$ (9D), $600 \mathrm{~mm}$ (12D) and $800 \mathrm{~mm}$ (16D) (Fig. 8). Installation condition followed the optimal rotation speed and weight of axial loading determined from single pile tests.

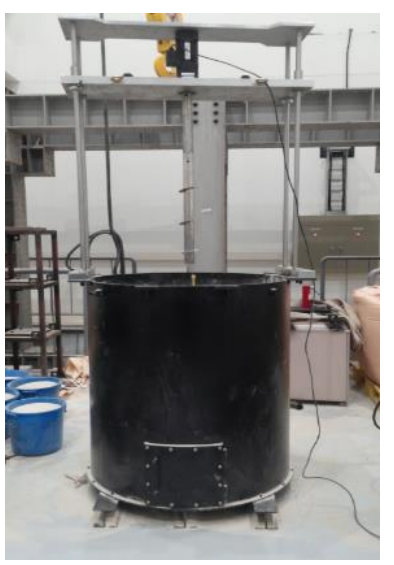

(a)

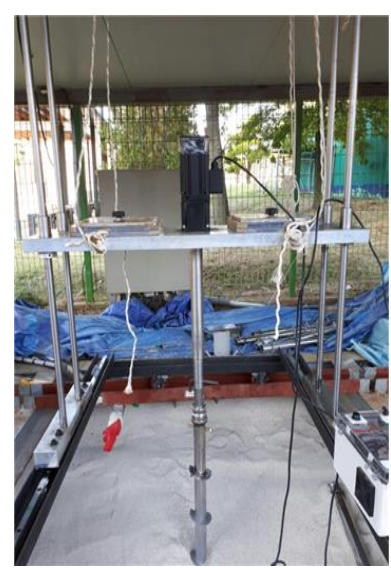

(b)
Fig. 6. Picture of pile installation devices; (a) Single helical pile and (b) Group helical pile

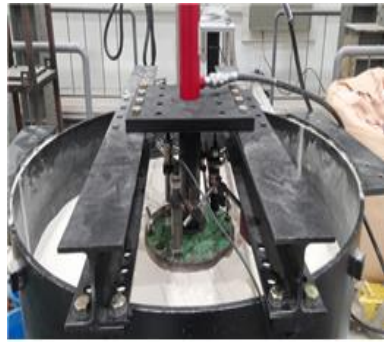

(a)

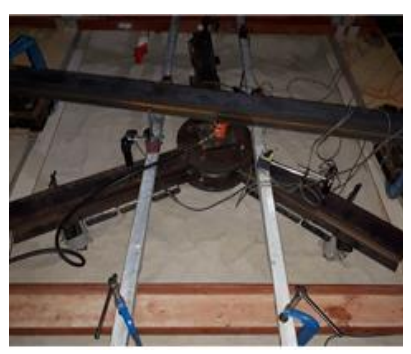

(b)
Fig. 7. Picture of pile load test; (a) Single helical pile and (b) Group helical pile

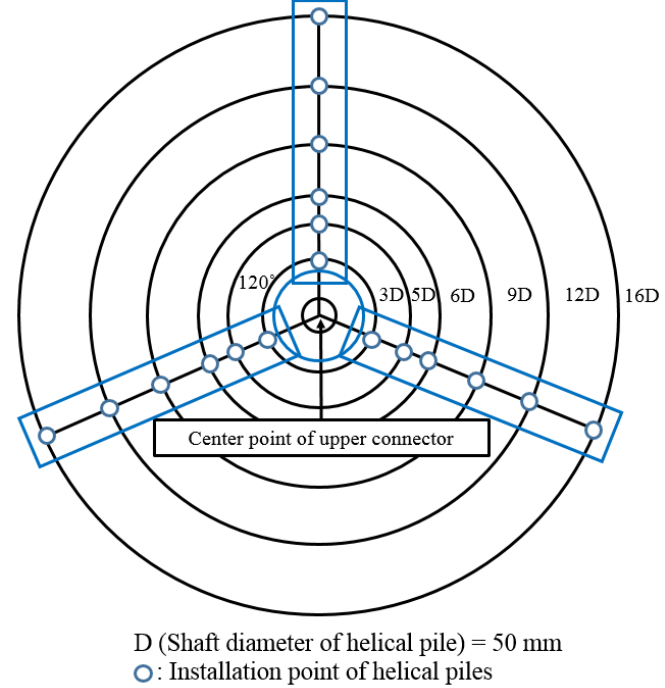

Fig. 8. Schematic description of group helical piles

\section{Test results}

\subsection{Behaviour of single helical piles}

Results of ultimate loads for single pile tests are shown in Fig. 9. Ultimate loads of helical piles increased with increasing helix spacing, and increased with increasing rotation speed and weight of axial loading during pile installation.

In particular, the ultimate loads of helical pile with 50 $\mathrm{mm}$ helix spacing were less influenced installation conditions. Whereas, the ultimate loads of helical pile with $150 \mathrm{~mm}$ helix spacing were influenced considerably. That means helical pile with $50 \mathrm{~mm}$ helix spacing, which is assumed as cylindrical shear method, is less sensitive to pile installation conditions. On the other hand, helical pile with $150 \mathrm{~mm}$ helix spacing, which is simulated as individual bearing method, is dependent on installation conditions. Also, rotation speed and weight of axial loading are important to increase of pile bearing capacity.

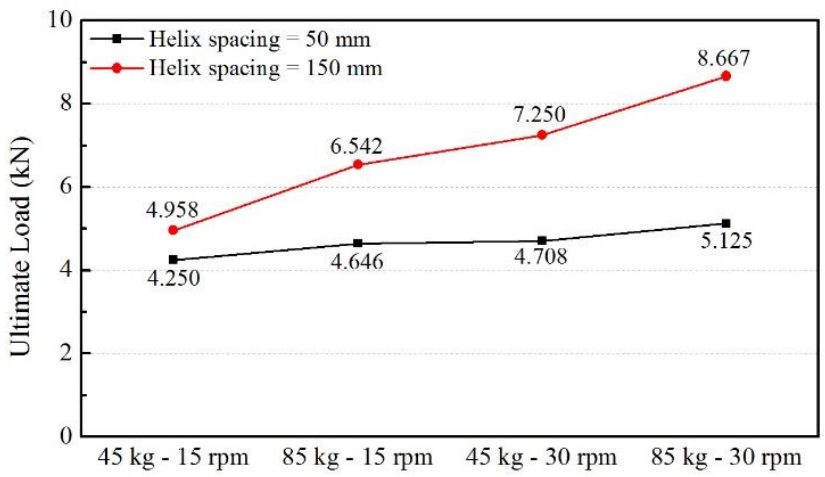

Fig. 9. Ultimate loads of two types of single helical piles varying rotation speed and weight of axial loading 


\subsection{Behaviour of group helical piles}

Results of ultimate loads for group pile tests are shown in Fig. 10. Each of helical piles was installed in sands depending on the optimal installation conditions determined from the single pile tests. Ultimate loads of group helical piles increased with increasing helix spacing. Also, ultimate loads of group helical piles with $50 \mathrm{~mm}$ and $150 \mathrm{~mm}$ helix spacing reached a peak at pile spacing of 5D $(250 \mathrm{~mm}), 6 \mathrm{D}(300 \mathrm{~mm})$, respectively, and decreased with increasing pile spacing.

Similarly to the results of single helical pile, the ultimate loads of group helical piles with $50 \mathrm{~mm}$ helix plate were less dependent on pile spacing from the center point, compared with helical pile of $150 \mathrm{~mm}$ helix spacing.

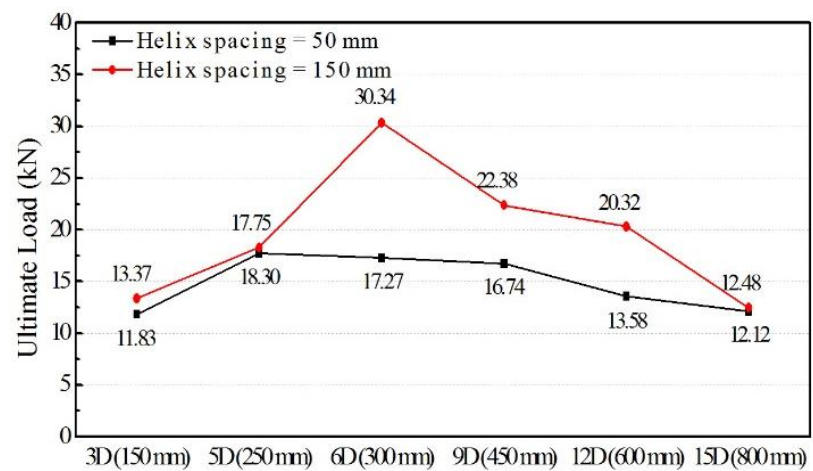

Fig. 10. Ultimate loads of two types of group helical piles varying pile distance from the centre point of upper connector

\section{Conclusion}

This study was conducted to analyse the behaviour of single and group helical piles in sands from pile load tests. The pile load tests for single helical piles were performed varying helix spacing, rotation speed and weight of axial loading. From the single pile tests, optimal conditions of pile installation were determined. The group pile tests were carried out varying helix spacing and pile distance from the centre point of upper connector. To remove effects of installation conditions in the test of group piles, each of helical piles was carried out following the optimum conditions determined from the results of single pile tests. The conclusions are as follows.

1) In case of single helical pile tests, the ultimate loads of helical piles increased with increasing helix spacing, rotation speed and weight of axial loading. Furthermore, the ultimate loads of single piles with lower helix spacing were less influenced by installation conditions.
2) In case of group helical pile tests, the ultimate loads of helical piles with $50 \mathrm{~mm}$ and $150 \mathrm{~mm}$ helix spacing reached the highest point at pile spacing of $5 \mathrm{D}(250 \mathrm{~mm}), 6 \mathrm{D}(300 \mathrm{~mm})$, respectively. In addition, similarly to the results of single pile tests, the ultimate loads of helical piles with $50 \mathrm{~mm}$ helix spacing were less dependent on the pile spacing from the centre point of upper connector.

\section{Acknowledgement}

The research (Project Number: 18IFIP-B089065-05) presented in this paper is supported by the Korea Agency for Infrastructure Technology Advancement under the Ministry of Land, Infrastructure and Transport of the Korean government. The authors acknowledge their support.

\section{References}

1. M. Sakr, "Installation and Performance Characteristics of High Capacity Helical piles in Cohesionless Soils', The Journal of the Deep Foundations Institute 5 :1, pp. 39-57 (2011)

2. M. Hesham, Y. Abdelghany, "Helical Screw Piles (HSP) Capacity for Axial Cyclic Loading in Cohesive Soils", Earthquake Geotechnical Engineering 4, p. 1567 (2007)

3. J. Lee, D. Lee, H. Kim, H. Choi, "Effect of Configuration of Shaft and Helix Plate on Bearing Capacity of Moderate-size Helical Pile : I. Test-bed Construction and Field Loading Test,' J. Korean Geosynthetics Society 13 :2, pp. 31 39 (2014)

4. M. T. Davisson, "High Capacity Piles", Proc. Lectures series on innovations in foundation construction, ASCE, Illinois Section, Chicago (1972)

5. M. T. Davisson, "Piles Load Capacity", Proc. ASCE Conf. Design Construction and Performance of Deep Foundation, ASCE, University of California, Berkeley (1975)

6. H. A. Perko, Helical piles: a practical guide to design and installation, John Wiley \& Sons (2009) 